\title{
Analisa Kepatuhan Mengonsumsi Antibiotik Pasien Demam Typhoid di Kecamatan Simpang Katis Kab. Bangka Tengah Tahun 2016
}

Muhammad Seto Sudirman

Poltekkes Kemenkes Pangkalpinang

Email : muhamadseto@gmail.com

\begin{abstract}
Abstrak
Demam Typhoid merupakan penyakit yang disebabkan oleh bakteri Salmonella Typhosa sp. Penunjang diagnosa demam typhoid melalui pemeriksaan laboratorium gaal kultur dan widal, namun gaal kultur memerlukan waktu lama, sehingga widal menjadi pilihan yang paling sering digunakan.Pengobatan utama demam tifoid dengan pemberian antibiotik. Penggunaan antibiotik harus tepat dan sesuai dengan aturan. Brunner \& Suddarth (2002) menyatakan bahwa kepatuhan yang buruk atau terapi yang tidak lengkap adalah faktor yang berperan terhadap resistensi individu. Penelitian bertujuan untuk mengetahui bagaimana Analisa Kepatuhan Mengonsumsi Antibiotik Pasien Demam Typhoid. Desain penelitian adalah retrospektif dengan melakukan Analisa Kepatuhan Mengonsumsi Antibiotik Pasien Demam Typhoid. Penelitian ini menggunakan pendekatan Cross Sectional. Variabel yang diteliti adalah variabel bebas/independent dan variabel terikat/dependent. Metode pengumpulan data penelitian ini menggunakan data primer (kuisioner dan pemeriksaan widal setelah menggunakan antibiotik) dan data sekunder (data penderita demam typhoid sebelum menggunakan antibiotik).Hasil penelitian dengan pearson rho adalah nilai sig (2-tailed) adalah 0,000, sebagaimana dasar pengambilan keputusan , maka dapat disimpulkan bahwa adanya hubungan signifikan kepatuhan minum obat dengan derajat kesembuhan hasil pemeriksaan widal
\end{abstract}

Kata Kunci : Antibiotik, Kepatuhan, Thypoid.

\section{Analysis of Antibiotics Intake Compliance of Patients with Thypoid Fever in Simpang Katis District, Bangka Tengah in 2016}

\begin{abstract}
Typhoid fever is a disease caused by Salmonella Typhosa sp. Typhoid fever diagnostic support through laboratory examination and culture widal widal, but the culture gaal takes a long time, so widal became the most frequently used option. The main treatment of typhoid fever with antibiotics. Use of antibiotics should be appropriate and in accordance with the rules. Brunner \& Suddarth (2002) suggest that poor compliance or incomplete therapy are factors that contribute to individual resistance. The study aims to find out how Compliance Analysis Consume Antibiotics Typhoid Fever Patients. The study design was retrospective by performing Compliance Analysis of Antibiotics on Typhoid Fever Patients. This research uses Cross Sectional approach. The variables studied are independent variable and dependent variable. Methods of data collection of this study using primary data (questionnaires and examination widal after using antibiotics) and secondary data (data of patients with typhoid fever before using antibiotics). Research results with pearson rho is sig (2tailed) is 0,000, as the basis of decision making, it can be concluded that there is a significant relationship of adherence to taking medication with the degree of healing of the results of examination widal.
\end{abstract}

Keywords: Antibiotics, Compliance, Typhoid Fever. 


\section{PENDAHULUAN}

Berdasarkan data Puskesmas Simpangkatis, pada tahun 2014 terjadi insiden demam typhoid sebanyak 48 kasus, pada tahun 2015 telah terjadi insiden demam typhoid sebanyak 21 kasus. Di daerah endemis malaria seperti Kepulauan Bangka Belitung ini, demam typhoid sering dikait-kaitkan atau disamakan dengan malaria. Padahal demam typhoid berbeda dengan malaria.

Thailand (1984) merupakan negara yang pertama kali melaporkan adanya demam typhoid, selanjutnya diikuti oleh negara lain, Demam Typhoid merupakan penyakit yang disebabkan oleh bakteri Salmonella Typhosa. Penunjang diagnosa demam typhoid melalui pemeriksaan laboratorium gaal kultur dan widal, namun gaal kultur memerlukan waktu lama, sehingga widal menjadi pilihan yang paling sering digunakan. Selain sebagai penunjang diagnosa, hasil pemeriksaan widal dapat menentukan derajat kesembuhan untuk pemantauan hasil terapi / pengobatan.

Pengobatan utama untuk demam tifoid adalah dengan pemberian antibiotik. Penggunaan antibiotik harus tepat dan sesuai dengan aturan. Jika tidak, dapat menyebabkan mikroorganisme penyebab penyakit, yang dalam hal ini bakteri Salmonella sp.menjadi kebal obat atau mengalami resistensi. Efeknya apabila penyakit demam tifoid dari spesies yang sama kambuh di kemudian hari, akan lebih berat untuk sembuh dan memberi peluang memudahkan spesies Salmonella lain untuk menyerang .

Kepatuhan atau ketaatan terhadap pengobatan medis adalah suatu kepatuhan pasien terhadap pengobatan yang telah ditentukan (Notoatmodjo, 2003). Brunner \& Suddarth (2002) menyatakan bahwa kepatuhan yang buruk atau terapi yang tidak lengkap adalah faktor yang berperan terhadap resistensi individu.

Beberapa tahun terakhir ini, ditemukan adanya kasus resisten terhadap antibiotik yang lazim digunakan untuk demam tifoid. Resistensi pada strain Salmonella typhi untuk kloramfenikol dilaporkan pertama kali terjadi di Inggris tahun 1950 dan di India tahun 1972. Resistensi tersebut ternyata diikuti oleh antibiotik yang lain, strain Salmonella typhi yang resisten terhadap ampisilin dilaporkan pertama kali di Meksiko tahun 1973. Pada perkembangan selanjutnya, beberapa negara melaporkan adanya strain Salmonella typhi yang telah resisten terhadap dua atau lebih golongan antibiotik yang lazim digunakan yaitu ampisilin, kloramfenikol, dan kotrimoksazol dinamai strain multi drug resistance (MDR) Salmonellatyphi. (Hadinegoro, 1999). Pemantauan terapi pengobatan sesuai aturan atau tidak, dapat diperoleh dari observasi secara langsung dan kuisioner terhadap pasien.Berdasarkan latar belakang diatas, peneliti bermaksud melakukan penelitian tentang "Analisa Kepatuhan Mengonsumsi Antibiotik Pasien Demam Typhoid Di Kec Simpang Katis Kab Bangka Tengah Tahun 2016".

\section{METODE}

Penelitian ini menggunakan pendekatan Cross Sectional. Variabel yang diteliti adalah variabel bebas/independent dan variabel terikat/dependent. Metode pengumpulan data penelitian ini menggunakan data primer (kuisioner dan pemeriksaan widal setelah menggunakan antibiotik) dan data sekunder (data penderita demam typhoid). Lingkungan studinya menggunakan studi eksperimen lapangan.

Populasi dalam penelitian ini adalah penderita yang demam typhoid. Teknik sampling penelitian ini menggunakan purposive sampling, dimana sampel diambil dengan kriteria yaitu positif demam typhoid. Teknik sampling secara purposive sampling yaitu sebanyak 47 orang penderita demam typhoid di wilayah kerja Puskesmas Simpang Katis.

Penelitian ini dilakukan pada pasien positif menderita demam typhoid di kecamatan simpang katis pada bulan Juni Agustus tahun 2016 dimulai dari Studi pendahuluan, pelaksanaan program dilakukan bulan Juni-Agustus 2016 dengan cara survey atau mendatangi rumah pasien yang tercatat sebagai penderita demam typhoid dengan kuisioner, melakukan pemeriksaan widal untuk memastikan derajat kesembuhan oleh petugas analis kesehatan, dan melakukan analisis data dengan chi square.

Analisis bivariat digunakan untuk mengetahui hubungan antara masing-masing variabel bebas (Independent) yakni kepatuhan konsumsi obat, variabel terikat (Dependent) yakni demam typhoid dan uji statistik Chi-Square.Analisis data dilakukan 
dengan perangkat lunak komputer dengan tingkat signifikan $\alpha=0,05$ (taraf kepercayaan $95 \%$ )

\section{HASIL DAN PEMBAHASAN}

\section{A. Kepatuhan Minum Obat}

Penelitian dilakukan kepada 47 responden di 9 desa kecamatan simpang katis mengenai kepatuhan minum obat. Responden yang telah tercatat di rekam medis, dilakukan pengukuran kepatuhan minum obat. Didapatkan hasil sebagai berikut :

Tabel 4.1 Hasil Kepatuhan Minum Obat di Kecamatan Simpang Katis Tahun 2016

\begin{tabular}{ccc}
\hline No & \multicolumn{1}{c}{ Variabel } & Jumlah \\
\hline 1 & $\begin{array}{l}\text { Kepatuhan Minum Obat } \\
\text { - }\end{array}$ & 27 \\
& $\begin{array}{l}\text { Patuh } \\
\text { mengkonsumsi obat } \\
\text { Tidak Patuh } \\
\text { mengkonsumsi obat }\end{array}$ & 20 \\
\hline
\end{tabular}

\section{Sumber Data Primer 2016}

\section{B. Derajat Kesembuhan}

Penelitian dilakukan kepada 47 responden di 9 Desa Kecamatan Simpang Katis mengenai Derajat Kesembuhan. Responden yang telah tercatat di rekam medis, dilakukan pemeriksaan widal kemudian dibanding hasil sebelum dan sesudah minum obat antibiotik. Didapatkan hasil adalah

Tabel 4.2 Hasil Derajat Kesembuhan di Kecamatan Simpang Katis Tahun 2016

\begin{tabular}{|c|c|c|}
\hline No & Variabel & Jumlah \\
\hline \multirow[t]{4}{*}{1} & Derajat Kesembuhan & \\
\hline & - Sembuh Tuntas & 12 \\
\hline & - $\quad$ Sembuh Tidak Tuntas & 22 \\
\hline & - Resistensi & 13 \\
\hline
\end{tabular}

\section{Sumber Data Primer 2016}

\section{Analisis Bivariat}

Penelitian Analisa Kepatuhan Mengonsumsi Antibiotik Pasien Demam Typhoid Di Kec Simpang Katis Kab Bangka Tengah Tahun 2016 menguji apakah terdapat hubungan antara kepatuhan mengonsumsi antibiotik dengan derajat kesembuhan. Hasil uji statistik menggunakan analisis statistik Spearman Rho.
Tabel 4.3 Hasil analisis Korelasi Spearman's rho

\begin{tabular}{llcc}
\hline & & $\begin{array}{l}\text { Kepatuhan } \\
\text { minum } \\
\text { obat }\end{array}$ & $\begin{array}{l}\text { Derajat } \\
\text { Kesehatan }\end{array}$ \\
\hline $\begin{array}{l}\text { Kepatuhan } \\
\text { minum } \\
\text { obat }\end{array}$ & $\begin{array}{l}\text { Correlation } \\
\text { Coefficient }\end{array}$ & 1.000 & $.684^{* * *}$ \\
& Sig. (2-tailed) & & \\
& $\mathbf{N}$ & $\mathbf{4 7}$ & .000 \\
$\begin{array}{l}\text { Derajat } \\
\text { Kesehatan }\end{array}$ & $\begin{array}{l}\text { Correlation } \\
\text { Coefficient }\end{array}$ & $.684^{* *}$ & $\mathbf{4 7}$ \\
& Sig. (2-tailed & .000 & \\
\hline
\end{tabular}

Berdasarkan output diatas diketahui bahwa $\mathrm{N}$ atau jumlah data penelitian adalah 47, kemudian nilai sig (2-tailed) adalah 0,000, sebagaimana dasar pengambilan keputusan , maka dapat disimpulkan bahwa adanya hubungan signifikan kepatuhan minum obat dengan derajat kesehatan hasil pemeriksaan widal. Selanjutnya, dari output diatas diketahui Correlation Coefficient sebesar 0,684, maka nilai ini menunjukan hubungan kuat antara kepatuhan minum obat dengan derajat kesehatan kesembuhan pasien demam typhoid.

Penelitian dilakukan kepada 47 responden di 9 desa kecamatan simpang katis mengenai kepatuhan minum obat. Responden yang telah tercatat di rekam medis, dilakukan pengukuran kepatuhan minum obat. Kepatuhan atau ketaatan (compliance/adherence) adalah tingkat pasien melaksanakan cara pengobatan dan perilaku yang disarankan oleh dokternya atau oleh orang lain (Smet, 1994). Kepatuhan pasien sebagai sejauh mana perilaku pasien sesuai dengan ketentuan yang diberikan oleh profesional kesehatan (Niven, 2002).

Ada 10 pertanyaan dalam penelitian ini utk mengambarkan kepatuhan minum obat," Apakah anda selalu meminum obat secara teratur tanpa di ingatkan oleh keluarga Apakah anda selalu meminum obat sesuai dengan dosis yang di berikan dari klinik/ rumah sakit, Apakah anda tidak menghentikan obat yang dikonsumsi sebelum waktunya ,Apakah anda mengetahui jadwal minum obat secara mandiri ,Apakah Keluarga tidak selalu mengingatkan anda dalam minum obat. ,Kepatuhan minum obat pada anda karena tidak ada pengawasan terapi dirumah, Pasien / keluarga pasien selalu menebus resep obatnya., Pasien patuh 
mengkonsumsi obatnya karena mengerti instruksi penggunaan obat, Keluarga selalu mengajak pasien untuk berobat melakukan jadwal kontrol ulang, Pasien minum obat secara teratur karena dibantu adanya pemberian label pada setiap kemasan obat. Kesepuluh pertanyaan ini akan memberikan gambaran kepatuhan responden minum obat antibiotik. Bila responden menjawab iya minimal 6 pertanyaan maka peneliti menyimpulkan bahwa responden telah patuh untuk mengkonsumsi obat.

Dari 47 responden dinyatakan patuh mengonsumsi obat sebesar 27 responden dan yang dinyatakan tidak patuh mengonsumsi obat sebesar 20 responden.

Jika pasien tidak patuh dalam mengonsumsi antibiotik maka akan menimbulkan penggunaan antibiotik yang tidak rasional. Salah satu masalah besar yang timbul dari penggunaan antibiotik yang tidak rasional adalah resistensi. Dalam kasus demam tyhoid, Jika kita tidak meminum antibiotik tepat waktu, atau tidak sampai habis karena merasa sudah sembuh, bakteri-bakteri di tubuh kita akan menjadi terlatih dengan "serangan" yang diberikan. Tidak hanya itu, mereka juga mengatur strategi agar dapat memodifikasi "serangan" sehingga mereka dapat menghindari "serangan" antibiotik dan menjadi kebal. Jika infeksi bakteri menjadi sulit diberantas maka berbahaya untuk tubuh. Oleh karena itu, konseling yang tepat dan didukung kepatuhan pasien yang tinggi merupakan salah satu pilihan utama dalam membantu penggunaan antibiotik secara benar.

Derajat Kesembuhan Demam Tifoid adalah penderita yang dinyatakan menderita Demam Tifoid yang dibuktikan dengan pemeriksaan laboratorium metode Widal dimana titer aglutinin bernilai $1 / 80$ atau lebih dan atau kenaikan yang progresif pada antisera $\mathrm{O}$ dan $\mathrm{H}$, sesuai dengan hasil pemeriksaan laboratorium Interpretasi hasil uji Widal adalah sebagai berikut :

1) Titer $O$ yang tinggi $(\geq 160)$ menunjukkan adanya infeksi akut

2) Titer $\mathrm{H}$ yang tinggi ( $\geq 160$ ) menunjukkan telah mendapat imunisasi atau pernah menderita infeksi

3) Titer antibodi yang tinggi terhadap antigen $\mathrm{Vi}$ terjadi pada carrier. Hasil pemeriksaan widal membandingkan sebelum dan sesudah pemeriksaan widal:
Tabel 4.3 Derajat Kesembuhan

\begin{tabular}{clrcc}
\hline No & \multicolumn{2}{c}{ Derajat } & Sebelum & Sesudah \\
\hline 1 & Sembuh & Tuntas & $1 / 320$ & Negatif \\
& (Menurun & hingga & $1 / 160$ & \\
& negatif) & & $1 / 80$ & \\
2 & Sembuh & Tidak & $1 / 320$ & $1 / 160,1 / 80$ \\
& Tuntas (Menurun & $1 / 160$ & $1 / 80$ \\
& $\begin{array}{l}\text { tapi masih bersisa) } \\
3\end{array}$ & & \\
Resistensi (Tetap & $1 / 160$ & $1 / 320$ \\
& atau Malah Naik dan \\
& $\begin{array}{l}\text { Bertambah spesies } \\
\text { baru) }\end{array}$ & & \\
& & & \\
\hline
\end{tabular}

Hubungan Kepatuhan minum obat dengan derajat kesembuhan adalah Berdasarkan output diatas diketahui bahwa N atau jumlah data penelitian adalah, kemudian nilai sig (2-tailed) adalah $0,000<0,05$, sebagaimana dasar pengambilan keputusan, maka dapat disimpulkan bahwa adanya hubungan signifikan kepatuhan minum obat dengan derajat kesehatan hasil pemeriksaan widal,. Selanjutnya, dari output diatas diketahui Correlation Coefficient sebesar 0,684, maka nilai ini menunjukan hubungan kuat antara kepatuhan minum obat dengan derajat kesehatan kesembuhan pasien demam typhoid. 27,7 \% resisten dikarenakan masyarakat mudah mendapat antibiotik di warung-warung, masyarakat suka menggunakan antibiotik semaunya sendiri tanpa ada pengetahuan tentang antibiotik. $25,5 \%$ sembuh tuntas, dilihat dari usia anakanak sehingga mereka masih pengawasan ortu terutama ibu. 46,8 \% sembuh tidak tuntas, rata-rata mereka menghentikan obat sebelum pada waktunya atau tidak dihabiskan. Ketika mereka sudah merasa baikan, obatnya dihentika

Penelitian mengenai analisis kepatuhan minum obat antibiotik pada pasien demam typhoid belum pernah dilakukan di Kecamatan Simpang Katis. Namun, sudah ada penelitian yang sama, tetapi pada penelitian yang dilakukan Renny Wulan Apriliyasar dengan judul Hubungan Antara Kepatuhan Minum Obat Dengan Tingkat Kesembuhan Pengobatan Pasien Tuberculosis Paru di BKPM Wilayah Pati. Pada hasil penelitian menunjukkan (p value $0,000<0,05)$. Sebanyak 3 responden $(6,67 \%)$ tidak patuh dan 42 responden $(93,33 \%)$. Serta 
didapatkan kesembuhan sebanyak 41 responden $(91,11 \%)$ sembuh dan 4 responden $(8,89 \%)$ tidak sembuh.Mayoritas Pasien Tuberculosis Paru patuh dan sembuh, serta

ada hubungan antara kepatuhan minum obat dengan tingkat kesembuhan pengobatan pasien Tuberkulosis Paru di BKPM Wilayah Pati.

\section{KESIMPULAN}

1. Adanya hubungan signifikan kepatuhan minum obat dengan derajat kesehatan hasil pemeriksaan widal dengan nilai sig $0,00<0,05$.

2. Jumlah Responden yang patuh mengkonsumsi obat adalah 27

3. Jumlah Responden yang tidak patuh mengkonsumsi obat adalah 20

4. Jumlah Pasien yang sembuh tuntas adalah 12 , yang resisten adalah 13, dan sembuh tidak tuntas adalah 22 .

\section{DAFTAR PUSTAKA}

Irianto, K. 2006. Mikrobiologi Menguak. Jakarta: CV. Yrama Widya

Jawetz, Ernest. 1996. Mikrobiologi Kedokteran. Jakarta: Buku Kedokteran EGC.

Muliawan \& Surjawidjaya. 1999. Diagnosis dini demam tifoid dengan menggunakan protein membran luar S. Typhi sebagai antigen spesifik .

Prasetyo, R. \& V. Ismoedijanto. 2009. Metode Diagnostik Demam Tipoid Pada Anak. FK UNAIR: Divisi Tropik dan Penyakit Infeksi Bagian/SMF Ilmu Kesehatan Anak.

Staff Pengajar FKUI. 1994. Mikrobiologi Kedokteran. Jakarta: Binarupa Aksara

Sudigdo Sastroasmoro. 2008. Dasar-dasar Metodologi Penelitian Klinis. Jakata: Binarupa Aksara.

Widodo, D. 2009. ,Demam Tifoi. Buku Ajar Penyakit Dalam. Jakarta: Interna Publising. 